Int. J. Morphol.,

28(4):1081-1086, 2010.

\title{
A Model for the Estimation of Personal Stature from the Length of Forearm
}

\author{
Un Modelo para la Estimación de la Estatura Personal desde la Longitud del Antebrazo
}

Isurani Ilayperuma; Ganananda Nanayakkara \& Nadeeka Palahepitiya

ILAYPERUMA, I.; NANAYAKKARA, G. \& PALAHEPITIYA, N. A model for the estimation of personal stature from the length of forearm. Int. J. Morphol., 28(4):1081-1086, 2010.

SUMMARY: Prediction of stature from incomplete and decomposing skeletal remains is vital in establishing the identity of an unknown individual. It has been stated that a variety of factors such as race, gender and nutrition play an important role in determining the height of an individual. Estimation of stature from measurements of various long bones has been achieved with varying degree of accuracy. Those studies resulted in establishing different formulae for the estimation of stature for the respective populations. However, evidence shows that there is a great void in such norms for Sri Lankans. Hence, this study was designed to investigate the relationship and to propose a gender and age specific linear regression models between the ulna length and height of an individual. A total of 258 subjects with an age span of 20-23 years were included in the study. The ulna length was measured using a digital sliding caliper capable of measuring to the nearest $0.01 \mathrm{~mm}$. The height of the individual was measured standing erect, in anatomical position using a standing height measuring instrument. The findings of the study indicated significant differences of the ulna length between the genders. A positive correlation between height and ulna length was observed in both sexes and it was statistically significant. Regression equations for stature estimation were formulated using the ulna lengths for both males and females. The ulna length provides an accurate and reliable means in estimating the height of an individual. The regression formulae proposed in this study will be useful for clinicians, anatomists, archeologists, anthropologists and forensic scientists when such evidence provides the investigator the only opportunity to gauge that aspect of an individual's physical description.

KEY WORDS: Height; Ulna; Sri Lankan; Regression equation.

\section{INTRODUCTION}

Height is fundamental to assessing growth and nutrition, calculating body surface area, and predicting pulmonary function in childhood (Gauld et al., 2004). It is known that trunks and limbs exhibit consistent ratios among themselves and relative to total body height. The ratios between body segments are age, sex and race dependent (Meadows, 1996; Meadows \& Jantz, 1999; Williams et al., 2000). Establishment of alternative methodologies for personal height estimation is important for a number of reasons. Firstly, in instances where height estimates needed to be made from fragments of bones in archeological procedures or in forensic examinations after mass disasters or genocide (Ebite et al., 2008). Secondly, estimates of pharmacokinetic parameters and evaluation of nutritional status rely on accurate measurement of not only body weight but also height. However, a number of common disabilities and disease processes make it difficult to accurately measure standing height in many patients (Auyeung et al., 2009).

The problem of correlating the length of the long limb bones with the height of the individual has confronted scientists for a long time. Various long bones have been employed for stature estimation using variety of methodologies (Telkka, 1950; Athawale, 1963; Joshi et al., 1964; Shroff \& Vare, 1979). Although many formulae for stature estimation from long bones have been proposed, there is concern regarding the accuracy of the use of population specific formulae on other human populations (Williams et al.; Duyar \& Pelin, 2003). For instance, Negros have comparatively long upper and lower limbs and consequently formulae designed to estimate height 
from that particular population may not apply to other populations in Asia (Ebite et al.). It is obvious that there are no universally applicable formulae for stature estimation from the length of long bones as the relationship between them is influenced by the race, sex and age of an individual. Thus, the need for race, age and sex specific stature estimation formulae is proved beyond doubt.

The ulna is a long bone on the medial side of the forearm. Proximally the ulna has a bony process called the olecranon process which articulates with the humerus. Distally the ulna bears a styloid process. The olecranon is subcutaneous and easily palpable. Its position depends on the angle of flexion-extension of the elbow joint. In extension, its tip is in line with the epicondyles of the humerus and in full flexion three bony points make an equilateral triangle. The whole length of the subcutaneous border of the ulna is palpable down to the styloid process (Sinnathamby, 1999; Williams et al.). Ossification of the ulna begins at the 8 th week of fetal life. The proximal epiphysis fuses with the shaft in $16^{\text {th }}$ year and the distal epiphysis unites with the shaft in $20^{\text {th }}$ year (Williams et al.).

The ulna length has been shown to be a reliable and precise means in predicting the stature of an individual (Gauld et al.; Ebite $e t a l$.). Despite its significance and practical use, there is a great void in such norms for Sri Lankans, inhabitants of the South Asian country, and hence, this study was designed to investigate the relationship and to propose population and gender specific regression formulae between the percutaneous ulna length and height of an individual.

\section{MATERIAL AND METHOD}

This study was conducted on 258 medical students (140 male and 118 female) of the Faculty of Medicine, University of Ruhuna, Galle, Sri Lanka. The subjects were apparently healthy and without any physical deformity. They were from different parts of the island belonging to different socio-economic status. The age of the subjects ranged from 20-23 years.

The ulna length was defined as the direct distance between the tip of the olecranon process and the styloid process while the elbow in full flexion (Ebite et al.). Ulna lengths were taken independently on left and right sides of each individual using a digital sliding caliper capable of measuring to the nearest $0.01 \mathrm{~mm}$ (Mitutoyo, Japan). The height of the individual was measured between vertex and the floor, when the person is standing erect, in anatomical position and the head in the Frankfort plane, using a standing height measuring instrument. Height was measured to the nearest $0.1 \mathrm{~cm}$.

All the measurements were taken at a fixed time between 14:00 - 16:30 hours to eliminate discrepancies due to diurnal variation. Furthermore, the measurements were recorded by the same person to minimize the errors in methodology. Each measurement was taken thrice and the mean was taken for further analysis. Results were expressed as mean \pm SD and analyzed using a statistical package SPSS $\left(15^{\text {th }}\right.$ version $)$.

\section{RESULTS}

The mean ages of the study subjects (male: $21.03 \pm$ 0.88 ; female $21.27 \pm 0.89$ ) were not significantly different between the genders. Statistical analysis indicated that bilateral variation was insignificant for the measurements of ulna length in both sexes. Therefore, the mean length of the left ulna was taken for further analysis.

Regression analysis was performed for estimation of stature using the ulna length as an independent variable. Various important parameters of the study subjects

\begin{tabular}{lcc}
\hline Parameter & Male & Female \\
\hline Total number & 140 & 118 \\
Mean age & $21.03 \pm 0.88$ & $21.27 \pm 0.89$ \\
Height range $(\mathrm{cm})$ & $159.5-183$ & $144-168.7$ \\
Mean height $(\mathrm{cm})$ & $170.14 \pm 5.22^{*}$ & $157.55 \pm 5.75$ \\
Ulna length range $(\mathrm{cm})$ & $24.50-31.00$ & $22.00-27.50$ \\
Mean ulna length $(\mathrm{cm})$ & $27.56 \pm 1.30^{*}$ & $25.11 \pm 1.24$ \\
Correlation Coefficient & 0.66 & 0.76 \\
Regression Coefficient & 2.645 & 3.536 \\
Value of Constant & 97.252 & 68.777 \\
\hline
\end{tabular}

Table I. Height, ulna length, correlation coefficient, regression coefficient and value of constant in males and females.

* $\mathrm{P}<0.0001$ when compared with the females. 


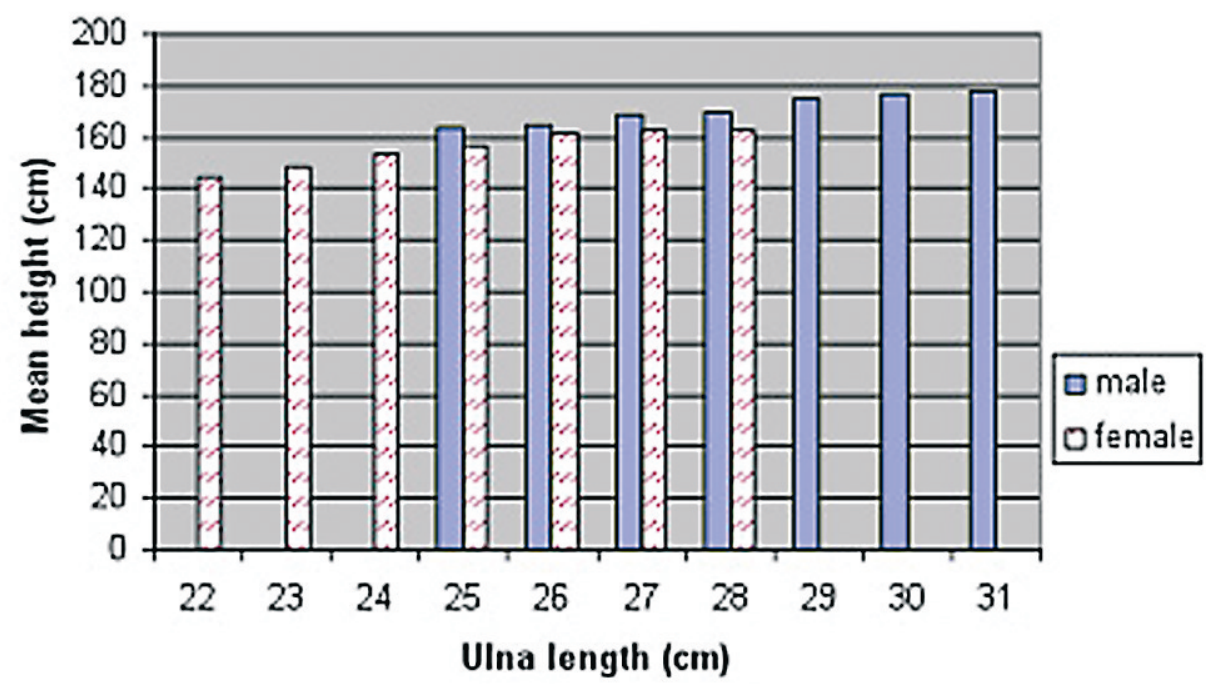

Fig. 1. Bar chart relating ulna length and mean height of males and females.

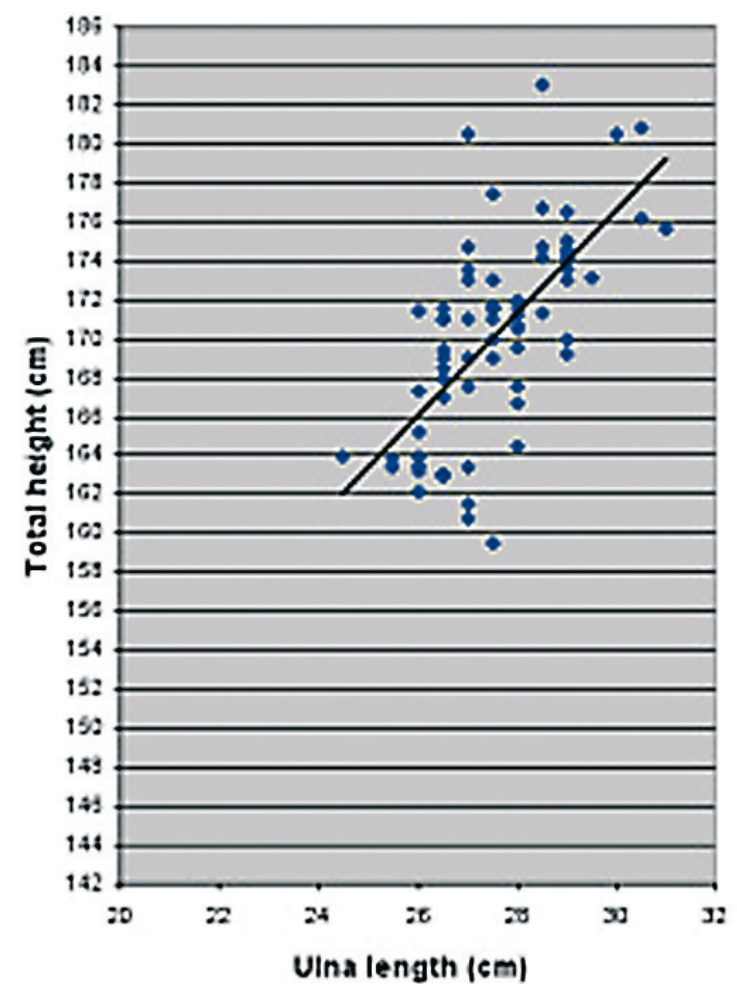

Fig. 2. Scatter plot and regression line demonstrating the relationship between the ulna length and total height of male subjects.

are summarized in Table I. Gender differences in mean height and ulna length were found to be highly significant $(\mathrm{P}<0.0001)$ (Table I and Fig. 1). Mean ulna lengths of the male were significantly larger than that of the females for all ages $(\mathrm{P}<0.0001)$ (Fig. 1). Pearson's correlation

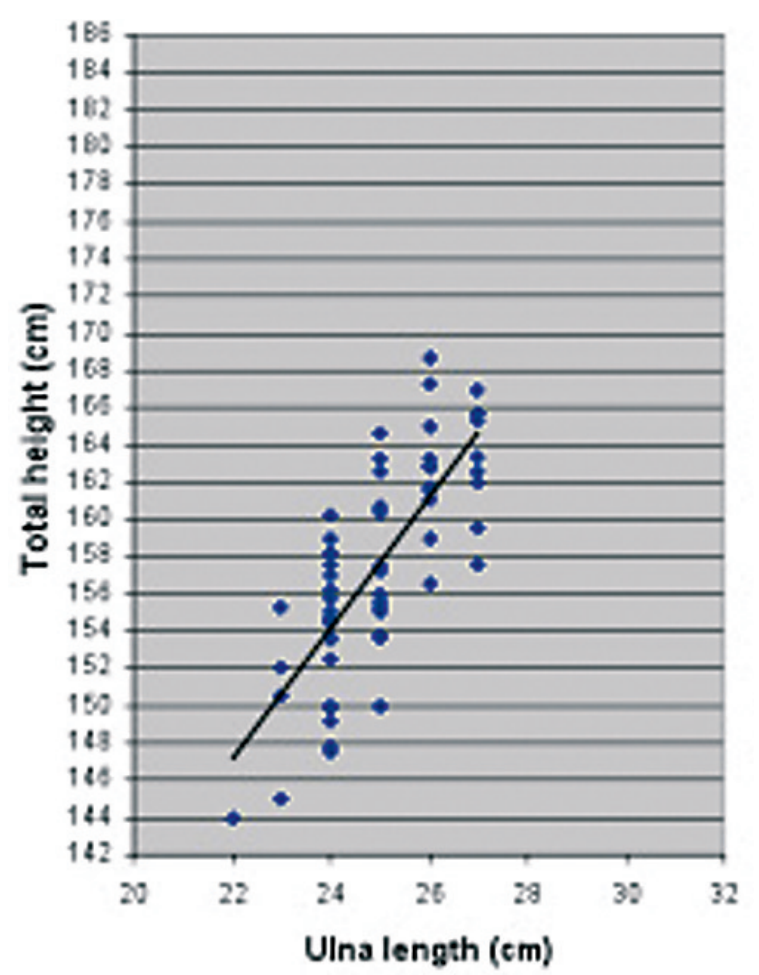

Fig. 3. Scatter plot and regression line demonstrating the relationship between the ulna length and total height of female subjects.

coefficient was used to examine the relationship between ulna length and height according to the gender. Correlation coefficient between total height and ulna length was found to be statistically significant and positive in both males and females (Figs. 2 and 3). 
Regression equations for stature estimation were derived as follows:

For male: Height $=97.252+2.645$ (ulna length)

For females: Height $=68.777+3.536$ (ulna length)

For both male and female (combined): Height $=57.385$ +4.047 (ulna length)

\section{DISCUSSION}

The measurement of height is essential for the calculation of body mass index, which is one of the most commonly used nutritional assessment variable. However, its measurement is not always practical in bedridden, old or frail patients that cannot stand or are suffering from deformities of the vertebral column (Auyeung et al.). In forensic examinations and anthropological studies, prediction of stature from incomplete and decomposing skeletal remains is vital in establishing the identity of an unknown individual (Ebite et al.). Therefore, formulae based on the ulna length provide an alternative stature predictor under such circumstances. The ulna has easily identifiable surface landmarks making the measurements possible even in compromised postures.

The average height of adult males within a population is significantly higher than that of adult females (Williams et al.; Ebite et al.; Ilayperuma et al., 2008). The results obtained in this study are in agreement with the above statement. There was distinct sexual dimorphism in the ulna length in our study group where it was significantly longer in males than in females, a result that reinforces the previous observations (Ebite et al.). Studies on secular change and allometry have demonstrated differential limb proportions between sexes and among population (Meadows; Meadows \& Jantz). The need for gender specific formulae is proved as the rate of skeletal maturity in males and females tend to vary during the course of development (Williams et $a l$.). Furthermore, racial variation in the relationship between ulna length and height has been clearly demonstrated by comparative studies between Black, White and Asian subjects (Madden et al., 2008). The results of the present study further highlight the racial diversity in mean ulna length.

Although variety of methodologies have been proposed to predict stature from long limb bones, regression analysis proved to be the easiest and the reliable method (Meadows; Meadows \& Jantz). Correlation coefficient between the total height and ulna length among Sri Lankans was found to be statistically significant and positive indicating a strong relationship between the two parameters. Regression models for stature prediction were formulated using ulna lengths and checked for their accuracy by comparing the estimated stature and the actual stature. The results further confirmed that ulna length provides an accurate and reliable means in stature prediction.

The ulna length was proven to be superior to arm span measurement (Gauld et al.) and hand length (Ilayperuma et al., 2009) in predicting height. Furthermore, linear regression equation of height on ulna length has definitive advantage over that of tibial length, as it can be useful in cases where the lower extremities are deformed along with the deformities of the trunk (Joshi et al.). Height estimation has also been attempted using the ratio between height and ulna length (Ebite et al.). Results obtained from a study that attempted to reconstruct stature from ulna length in Hindu population in Gujarat state demonstrated a regression coefficient between height and ulna length to be +3.506 for males (Joshi et al.). The present study shows a regression coefficient of +2.645 for males and +3.536 for females.

Variety of factors such as, age, race, gender and nutritional status affect human development and growth and therefore, different nomograms are required for different populations (Williams et al.; Joshi et al.). The present study for the first time documents norms for height and ulna length and presents gender specific linear regression models for stature prediction in adult Sri Lankan population. The formulae are valid for the age group (2023 years) of the subjects. Since the height is shown to progressively decrease with advancing age due to spinal cord shrinkage (Williams et al.), it is recommended that similar studies on different age groups should be carried out to complement the results of the present study. The regression models proposed will be of immense practical use in clinical practice, medico-legal, anthropological and archeological studies where the total height of a subject can be calculated if the ulna length is known.

\section{ACKNOWLEDGEMENT}

The authors wish to thank Dr. W. A. A. Wijeyasiri, Department of Community Medicine, Faculty of Medicine, University of Ruhuna, Sri Lanka, for advising with the statistical analysis. 
ILAYPERUMA, I.; NANAYAKKARA, G. \& PALAHEPITIYA, N. Un modelo para la estimación de la estatura personal desde la longitud del antebrazo. Int. J. Morphol., 28(4):1081-1086, 2010.

RESUMEN: La predicción de la estatura a través de restos de esqueletos incompletos o en descomposición es de vital importancia para determinar la identidad de un individuo desconocido. Se ha dicho que la variedad de factores como raza, sexo y la nutrición juegan un papel importante en la determinación de la altura de un individuo. La estimación de la estatura a partir de mediciones de varios huesos largos se ha logrado con diversos grados de precisión. Los estudios han resultado en el establecimiento de fórmulas diferentes para la estimación de la estatura de las poblaciones específicas. Sin embargo, la evidencia muestra que existe un gran vacío en las normas para ciudadanos de Sri Lanka. Por lo tanto, este estudio fue diseñado para investigar la relación y proponer modelos de regresión lineal específicos en relación al sexo y la edad, entre la longitud de la ulna y la altura de un individuo. Un total de 258 sujetos con un rango de edad de 20-23 años se incluyeron en el estudio. La longitud ulnar se midió con un caliper digital deslizante, precisión de $0,01 \mathrm{~mm}$. La altura del individuo se midió de pie, en posición anatómica con un instrumento de medición. Los resultados del estudio indicaron diferencias significativas de la longitud de la ulna entre los géneros. Se observó una correlación positiva entre la altura y la longitud ulnar en ambos sexos, siendo estadísticamente significativa. Las ecuaciones de regresión para la estimación de la estatura se calcularon usando las longitudes de la ulna tanto en hombres como en mujeres. La longitud de la ulna es un medio preciso y fiable en la estimación de la altura de un individuo. Las fórmulas de regresión propuestas en este estudio serán útil para los médicos, anatomistas, arqueólogos, antropólogos y científicos forenses cuando la evidencia de ese tipo permita al investigador evaluar este aspecto de la descripción física de un individuo.

PALABRAS CLAVE: Altura; Ulna; Sri Lanka; Ecuación de regresión.

\section{REFERENCES}

Athawale, M. C. Anthropological study of height from length of forearm bones. A study of one hundred Maharashtrian male adults of ages between twenty five and thirty years. Am. J. Phys. Anthropol., 2:105-12, 1963.

Auyeung, T. W.; Lee, J. S. W.; Kwok, T.; Leung, J. Leung, P.C. \& Woo, J. Estimation of stature by measuring fibula and ulna bone length in 2443 adults: J. Nut. Health Aging., 10:931-6, 2009.

Duyar, I. \& Pelin C. Body height estimation based on tibial length in different stature groups. Am. J. Phys. Anthropol., 122:23-7, 2003.

Ebite, L. E.; Ozoko, T. C.; Eweka, A. O.; Otuaga, P. O.; Oni, A. O. \& Om'Iniabohs, F.A.E. Height: Ulna Ratio: A Method of Stature Estimation In A Rural Community in Edo State, Nigeria. The Internet Journal of Forensic Science, 3(1), 2008.

Gauld, L. M.; Kappers, J.; Carlin, J. B. \& Robertson, C. F. Height prediction from ulna length. Dev. Med. Child Neurol., 46(7):475-80, 2004.

Ilayperuma, I.; Nanayakkara, B. G. \& Palahepitiya, K. N. A Model for reconstruction of personal stature based on the measurements of foot length. Galle Med. J., 13:6-9, 2008.
Ilayperuma, I.; Nanayakkara, B. G. \& Palahepitiya, K. N. Prediction of personal stature based on the hand length. Galle Med. J., 14:15-8, 2009.

Joshi, N. B.; Patel, M. P. \& Dongre, A. V. Regression equation of height from ulna length. Ind. J. Med. Res., 52:1088-91, 1964.

Madden, A. M. T.; Tsikoura, T. \& Stott, D. J. The estimation of body height from ulnar length in adults from different ethnic groups. J. Hum. Nutr. Diet., 21(4):394, 2008.

Meadows, L. Secular change and allometry in the long limb bones of Americans from the mid 1700 through the 1970s. Knoxville, Tennese, University of Tennese, 1996.

Meadows, L. \& Jantz, R. L. Secular changes in long bone length and proportion in the United States 18001970. Am. J. Phys. Anthropol., 110:57-67, 1999.

Shroff, A. G. \& Vare, A. M. Determination of height from length of superior extremity and its' segments. J. Anat. Soc. India., 28:53-7, 1979.

Sinnathamby, C. S. Last's Anatomy Regional and Applied. 10 ${ }^{\text {th }}$ Ed. Edinburgh, Churchill Livingstone, 1999. 
ILAYPERUMA, I.; NANAYAKKARA, G. \& PALAHEPITIYA, N. A model for the estimation of personal stature from the length of forearm. Int. J. Morphol., 28(4):1081-1086, 2010.

Telkka, A. On the prediction of stature from the long bones. Acta Anat., 9:103-17, 1950.

Williams, P. L.; Bannister, L. H.; Berry, M. M.; Collins, P.; Dyson, M. \& Dussek, J. E. Gray's Anatomy: The Anatomical basis of medicine and surgery. $38^{\text {th }}$ Ed. New York, Churchchill Livingstone, 2000.

\author{
Correspondence to: \\ Dr. Isurani llayperuma, Ph.D. \\ Department of Anatomy, \\ Faculty of Medicine, \\ University of Ruhuna, \\ P.O.Box 70, Galle, \\ Sri Lanka \\ Telephone: 0094-91-2234801 \\ Fax: 0094-91-2222314 \\ Email: iisurani@yahoo.com
}

Received: 09-06-2010

Accepted: 17-08-2010 